


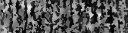

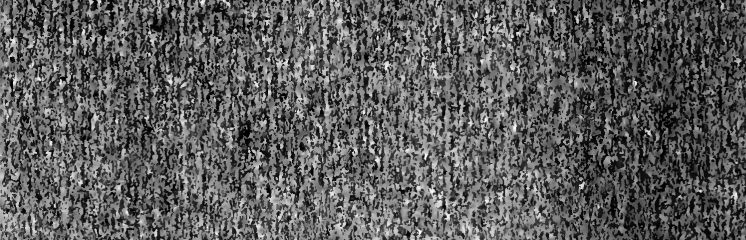

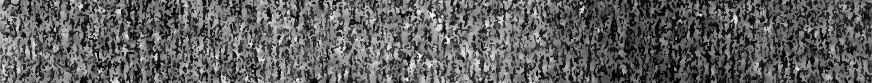
4.

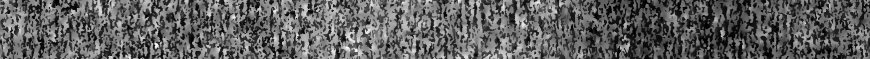
(3)

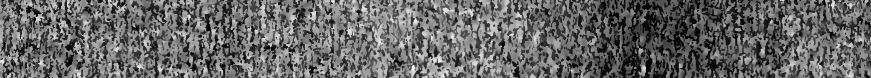

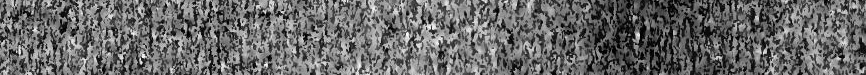

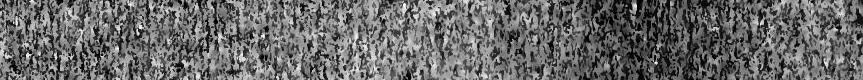

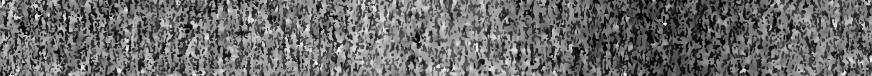

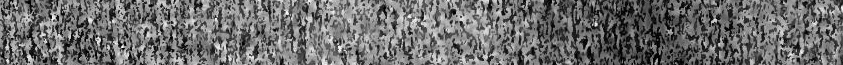

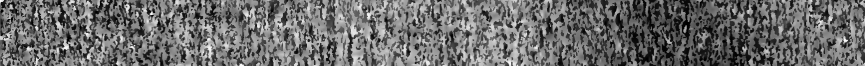

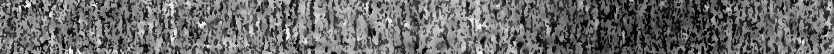
1.7.2.

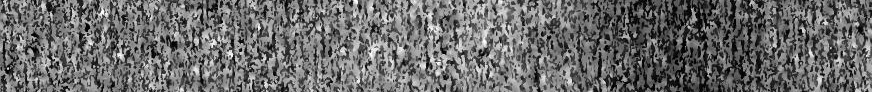
3.

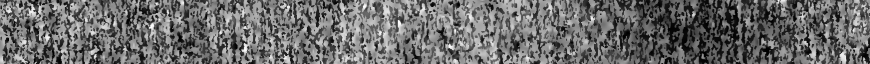
24. 1. 2. W.

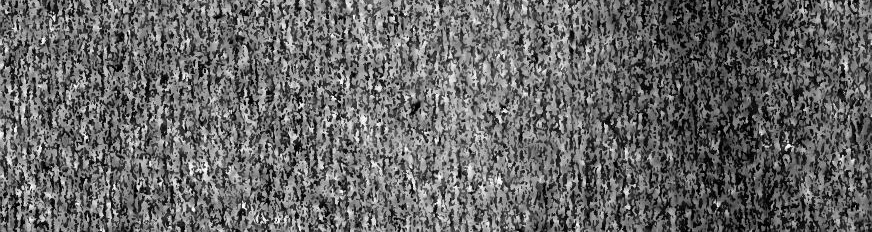




\section{$A \mathrm{D}$ D $\mathrm{RSS}$}

T O T II E

\section{PEOPLE OF}

\section{GRET BRITAIN,}

ON THE PROPRIETY OF ABSTAINING FROM

\section{Weit India Sugar and Rum.}

Why did all-creating Nature

ilake the plant for which we toil?

aghos muf fan it, Tears mufi water,

Sareat of curs muft drefs the Scil.

Think ve Nafers, iren-hearted,

Lolling at your jovial Borards:

Think how many Backs hate fmarted

Fur the Suects your Cane affords!

CowPER's Negro's Complaini,

The Tenth Edition, with Aduitions.

LONDON, PRINTED, PHILADELPHIA : RE-PRINTED BY DANIEL LAWRENCE, M.DCC.XCII. 


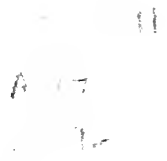

$\cdots$

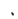

$\therefore:$ 
TOrwihfanding the late deternination of the Houfe of Commons on the Slave-Trade, we m.y hope that the difcufion it has received will notbe ufelefs; and that the public attention has not beea excited in vain, to a fyften of cruelty which it is painful even to recite. It may be hoped that, chaining for ourfelves the mon perfeet fretiom, we hat no longer impore upon others a llavery the moft opprefive; and that, enjoying a degree of felicity unequalled in any age or country, we thall no longer range the world to increafe the mifery of mankind.

The luf of power, and the pride of conqueft, have doubtiefs produced infances far too numerous, of nan enflaved by man. But we, in an enlightened age, have greary furpafed, in brutality and injuftice, the moft ignorant and barbarous ages: and while we are pretending to the finet feelings of humanity, are exerciting unprecedented cruelty. We have planted fiavery in the rank foil of fordid avarice; and the produce his been mifery in the exireme. We have afcerrained, hy a courfe of experiments in cructy, the leat portion of nourithnent requifte to enable man to linger a few years in mifery; the geateft quantity or labor which, in fuch a fituation, the extreme of pultinment can exturt; and he utmot degree of pain, labor, and humer anted, that the buman frame can. endure.

in vin have fuch fremes ben developed. The weath derived from the herrid tratio has credted

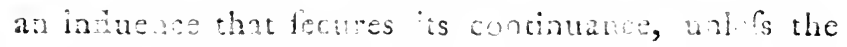

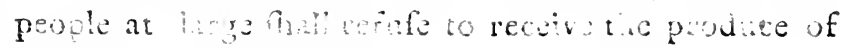
robbery and momer.

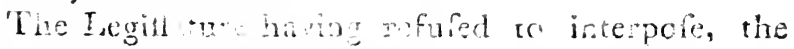

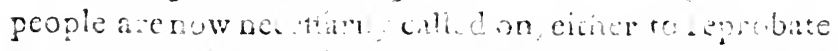

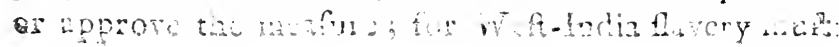


depend upon their fupport for its exiftence; and it is in the power of every individual to increafe, or to diminih its extent. The laws of our country may indeed probibit us the fugar-cane, unlefs we will receive it through the medium of favery. They may hold it to our lips, feeped in the blood of our fellow-creatures; but they cannot compel us to accept the loathfome potion. With us it refts, either to receive it and be partners in the crime, or to exonerate ourfelies from gullt, by fpurning from us the temptation. For let us not think, that the crime refts alone with thofe who conduct the traffic, or the Legifature by which it is proteded. If we purchafe the commodity, we participate in the crime. The flave-dealer, the fare-holder, and the flavedriver, are virtually the agents of the confumer, and may be confidered as employed and hired by him to procure the commodity. For, by holding out the temptation, he is the original caufe, the fret mover in the horrid procefs; and every diftinction is done away by the moral maxim, That whatever we do by another, we do ourfelves.

Nor are we by any means warranted to confider our individual thare in producing thefe evils in a trivial point of view. The confumption of fugar in this country is fo immenfe, that the quantity commonly ufed by individuals will have an important effect. A

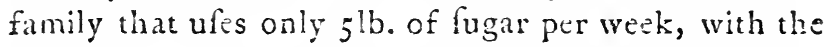
proportion of rum, will, by abfaining from the confumption 21 months, frevent the flavery or murder of one fellow-creature; eight fuch families in $19^{\frac{1}{2}}$ years, prevent the flavery or murder of 100 , and 38,000 would totally prevent the Slave-Trade to fupply our inands. Nay, fo neceffarily conncesed are our confumption of the commodity, and the mifery 


\section{$(5)$}

chuting from it, that in every pond of frgar wed,

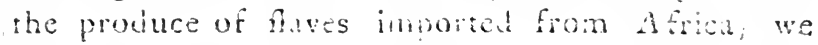
may be confidered as confuning two onnces of human towh, befiles deferoying an atarang number of feamen by the Slave-itade, and fircaling inconccivabie anguih, terror and dimay, through an inmenfe continent, by the burning of thei: villages, tearing parents from their fanile's, and ctillien from their parents; breiking every bond of fociey, and defruying every fowce of human happeis. A Fench writer obferves, "That he cannot look on a piece of fugar, whthout conceiving it flained with fpots of human blood :" and Dr. Franklin adds, that had he taken in all the confequences, "he might have feen the fugar not merely fpotted, but thoroughly dyed fcarlet in grain."

Dreadful confideration---that our increafing happinefs and profperity has fpread defolation and mifery over a country as large as all Europe! For it is an indifputable fad, that it is Britifn luxury, the African Slave Trade depends on for fupport: they have increafed, and they would fall together. Fcr our confumption of figar is now fo immenfe, that it nearly equals that of all Europe befides; and Jamaica now fupplies more than all our Wert-India. Iflanc's did at any period prior to $1755^{\circ}$

But amazingly extenfive as is the increare of the culture, fo far is it from keeping pace with our luxury, that (before the difurbances in the French Itlands, within thefe two or three years) fugars have ever fold in the Brition market 20 or 30 , fometimes 50 per cent. dearer than in ariy other part of the world. Nor is it to fuppoit the old plantations, as is pretended, but to form new ones, for the fur. 


\section{$(6)$}

ply of this our incteating luxury, that the wretch ed Africans are torn from their natse land.

Let es then imagine our imnenfe confumption wholiy, or in great part to ceafe, and our fapars to be thrown on the foreign markets; would additional flaves be wanted to fupply an overilowing market at a faliing price? No: the African Slave Trade, by whomfoever condicted, to fupp'y fugar colonies, by whatever nation pofiefled, muft totally ceafe. Horror and difnay would give place to peace and civilization, through a coat of above thee thoufand miles extent, and abrve a thoufand miles inland: for fo extenfive are our depredations, and fo extenfive are the benefits which it is in our power to confer. Nor would the beneficial effeets ceafe, even here. The Weft-India iflusds, finding lefs demand for fugar, muft appropriate lefs ground to the fugar-cane, and leave more for provifions: the flaves would be lefs worked, better fed, and in a few years confift intirely of native Creoles. Or if the planters appropriate the land to the other productions of the in:tnds, the fame beneficial effects muit enfue. For M. Cooke telis us, "the cultivation of coiton, pimento, and " coffee, is eafier than fugar: the flaves look better, and increafe fatter;" and inftead of requiring additional thaves, they would be able to increafe their plantations with thofe already in the iflands. For Governor Parry fays, "one acre of fugar requires as " much libour as three of cotten." Thus our re. fraining from the confumption of the fugar-care, even for a few years, woukd deftroy the Slave Trade to the Weft-India Ifands, bring frept lard into culture, and place the flaves in fuch a fituation, that they mufe rapidly increare. 


\section{$(7)$}

The diminution of the confumption of Theft India produce, would alfo have a powertul effect bo finking the price of the commodity; and therby take away the temptation to import additional naves. The effect a fmall variation in the fupply or danand has on the price, we have recently experienced. The difurbancs in the French fugar itlands, has fuddenly raifed for e of the markets, which were 20 or 30 per cent. lower than the Britih, much above it; and thereby occafioned an exportation from this courtry to fupply the deficiency: and our exportation, though cnly anounting to a roth of our importation, has raifed our fugars 50 per cent. And as a fill in the price would obftrue the Slave Trade, and melio:ate the condition of the flaves for this rife will produce efiecis the moft baneful. The planter, tempted hy the high price to get fugar and rur: to maket while that high price continues, will deprive his flaves of thi ir provition grounds, to plant them with canes; and by the energy of the whip, they will be forced to the mofextreme cxertions. The murder, or, in the technical language of the Went-Indies, the lofs of his flues, will be to him but a lecondary confideration. The large crop, and the high price, will amply compenfate him: and the queftion now is, not merely wherher we thall hold out to him an inducement to purchafe additional flaves; but whether we fiall tempt hin to murder thofe he already has. We con hardly d mbt, but that Weft India packets have a'ready borne the murderous difpatches, expreffed in lariglage ton dadafully explicit, and to the following eficet. "The price of fugar and rum ftill continues "high. You nint idopt every mode to for ward is "linge a cargo as pollible. $\Lambda$ forturite crifis nuw " ofius itfelf for cxiricating my eftate fro the diti- 
"culties in which it is involved. We muft avall onr"files of it: anoher may never nccur. Conte"quences, though diagrotable, muft at the prefent " moment be oremooked. The flave market is fill "open tor a freppig. Now-fangled bumanity is $n$ "more." The day hardy dawn when the whip re. founds theote hole regions of horror; nor ceates, thl darknels chufes the fene, which day arter ray is senewed The nifuble vions, dentute of every fource of comfort to body re to mind, and firking under the three endemic diferfes of our ilands, humger, tomer and extreme labour and urged to $\mathrm{ex}$ ertions they are unable to fuftain, at lengeh expite beneath the lafh, which in vain endeavours to roufe them to a renewal of their labour.

As neither the fare-dealer, nor the planter, can have any noral right to the perfon of him they file thir flave, to his labour, or to the produce of it; fo they can convey no right in that produce to us: and whatever number of hands it may paisthro' if the criminal circumftances appertaining to it be known to them at the time of the transer, they can ony have a criminal pofiffion: and the money paid, either for the flute, or for the produce of his labour, is paid to obtdin that criminal puffefion; and canconfer no moral right whatever, So, if the death of the perfon called a flive, be ccrafoned by the criminal pofforion, the criminal poffines is guity of murcer; and we, who have knowingly done any aet which mist occation his being in that fituation, are acceifari s th the nurder before the fact; as by rectiving the produre of his labour, we are acceflaries to the robie:y, after the fact.

f: , andiviluals conccrned in the Slave 'Trade (either by procuring the Aavts, compelling them to 


\section{$(9)$}

labour, or receiving the produce) imagine that our fhare in the tranfaction is fo minute that it cannot perceptibly increafe the injury; let us recolect that, though numbers partaking of a crime nay diminifh the fhame, theycannot dininifh its turpitude. Can we fuppofe, that an injury of enormous magnitude can take place, and the criminality be deftroyed merely by the criminals becoming fin nun.erous as to render their refpective thares in cinfinguifhable? Were an hundred affafins to plunge their daggers into their vicim, though each might piead, that without his aliftance the crime would have been compleated, and that his poinard neither occafioned nor accelerated the murder, yet every one of then would be guilty of the intire crime. For into how many parts foever a criminal action may be divided, the crime itfelf refts intire and compleat on erery perpetiator.

But waving this latter confideration, and even fuppofing for a moment, that the evil has an exiftence from caufes totally independent of us, yet it exifts; and as we have it in our power jointly with others, to remedy it, it is undoubtedly our duty to contribute our fhare, in hope that cthers will theirs; and to act that part from confcience, which we fhould from inclination in finilar cafes that intereftec our feelings.

For inftance: Let us fuppofe the Algerines to eftablith fugar plantations, and refort tr the banks of the Thames for flaves, as the only place to be infulted with inpunity. Suppofe our wives, our hufbands, our children, our parents, our biethren, fwept away, and the fruit of their labour, produced with agonizing hearts and trembling limbs, landed at the port of London. What would be our conduct? Should we fay, Sugar is a neceffary of life? I cannot do without it. Betides, the quantity I ufe is but a fmall propor- 


\section{( 10$)$}

tion: and though it is very criminal of the Algerines to enflave others, yet I am not bound to bout: to the nature or confequences of the trantaction; and paying for the fugar, I have a right to confunie it, however it may have been obtained. If fuch would bz our language in that cafe, be it fo on the pretent occafion For let us reccliter, that the oniy diference is, that in one cafe our relation to the enlaved is rather more renote, but that in both cafes they are our brethren.

But it is hardly requifite to falte fo ftrong a cafe as that fuppofed. For were oniy one Elgl:l man to receive injuries, that bore but the flighteft retombance to thofe daily committed in our iflinds, the nation would be infiamed with refentment, and clamorous to avenge the injury. $\Lambda$ nd can our pride fuggeft to us, that the rights of men are limited to any nation, or to any colour? Or, were any one to treat a fellow creature in this country as we do the unhappy Africans in the Weft-Indies; ftruck with horror, we flould be zealous to deliver the opprefled, and punith the oppreffox. Are then the offices of humanity and functions of juftice to be circumforibed by gecgraphical boundaries? Can reafon, can confcience jufity this contraft in our conduct, between our prompritude, in the one cafe, and our torpor in the other? Mir. Addifon juftly obferves, that "humanity to become eftimable mult be combined with juftice!" But we feem to act as if we thought that the relief of our fellow-creatures; protection from injuries, comnunication of bencfits, were works of fupererogation, to be granted or with-held, as caprice, or cuftom, or inclination may fuggef.

After the inportant confiderations adduced, it might be reckoned a degradation of the fubject to 


\section{(II)}

mention the national diguity; or even that might induce us to countialet a powerful body of men, who are trampling under foot the distates of humanity, and the interef of the vation: men, who have in 50 years received for fugar alone, above 70 millions more than it would have coft at any other market. And from Mr. Bothan's evidence it apperts, that in Batavia, where labour is as high as in England, fugar, equal to the beft Weft-India, is fold at id half penny per pound. Thefe are the men, who are endearouring to overthrow a plan for fupplying us with fugars, by means of free labour; and have the audaciry to tell the Britifh legillature, "That they cannot abulin the flave trade; for that if England refure to furvith them with flaves, they will obtain a fupply through other charne!s." And a governor of Barbadoes aimonithes us, "From policy, to leave the iflands to the quiet management of their cwn affairs." Thefe nominal colonies have, it feems, been taught, that we have no right to controul them; that the acts of their Arembirs alone are obligatory; and that thofe of Britin legndtors, are binding only on thofe whom they repreicnt. The right of in flaving others, they contend for, as the moft valuable of their privileges.

Thus it appers, that the legilature is not only unwilling, but pertans unable, to grant redrees; and therefore it is more pecularly incumbent on us, To

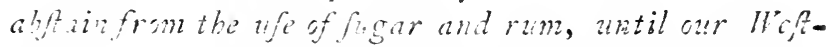
India Planters themfeles buac robioited the insortation of alulitional haves, and comnenced as fieedis and

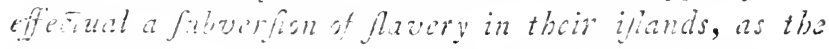
ciramfances and fituation of the facies will admit : or ti'l we can stain the probuce of the fugar cane in fone

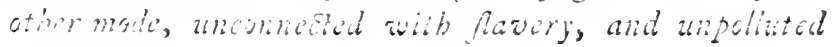
inth bical. 


\section{( 12$)$}

For furely it may be hoped that we hall not limit our views merely to the abolition of the African nave trade, as the colonial flavery formed on it, is in its principle equally unjuft. For if it be iniquitous to force the Africans from their native land; equaliy iniquitous muft it be, to retain them and their pofte. sity in perpetual bondage. Though the African flave trade be the moft Promirent feature in this wickednefs, jet it is but a feature: and where it abolihed, the Weft India flavery would ftill exift. Our planters would breed, inftead of importing faves; and frall wefuffer half a million of feilow fubjects, and their pofterity, to be held in flavery for ever? I fay, fellow fubjects. For undoubtedly, every perfon born in the dominions of Great Britain is a fubject, bound to obey and entitled to the protection of the common law of England; and in oppofition to which the acts of Afiemblies, exifting merely by grant from the crown, can be of no authority.

In demanding liberty then for the perfons called flaves in our iflands, we demand no more then they are entitled to by the common law of the land. The moft eligible mode of putting them in pofieffion of their legal and natural right, may be a queftion of difficulty; but it is a queftion that ought to be confidered with no other view, but to their happinefs. 'The plan to be adopted, ought to be certain and fpeedy in its operation; without any confideration of the fuppofed, or even real intereft, of their oppreffors: and let it bc remembered, that it is in the power of a fmall proportion of the people of England to cfiect it, by refufing to receive the produce. For the planters themfelves would adopt the plan, were that the only condition on which we would confune the produce of their ifiands: nor would the legifiture te 


\section{$(13)$}

then hararid with papoferous claims for compenfution; which, however mfoundcu in juftice or reafon, will be fupporicd by infucuce, andenforced with clamour.

The cale now fully lies before us; and we have to make our chuice, cither to join omfelves with thefe manuficturers of human wce, or to renounce the horrid affociation. If we adopt the former, let us at leaft have the candour to avow om conduct in its real deformity. Set us no longer affect to deplore the calanities attendant on the Slave Trade, of which we are the primary caufe: nor let us pretend to execrate the conduft of the have-tealer, the flave-holder, or the nave-driver; but ayologize for them as our partnel's in inicuity: and be affired, that if we now take our thare in the tranfaction, we fhould, were we placed in a fimilar fituation with them, with as lirte compunction take theirs; unlefs we can fuppofe the order of nature would be fo far inverted, as that we fhould become virtuous, in proportion as the temptation to vice increafed. For thould we then, any more then now, be deftitute of fubterfuges to deftroy the feelings of our misu's, and the convictions of ous confiences.

If ignorance and inattention may be pleaded as our excufe hitherto, yet that can be the cafe no longer. The fubject has been four years before the public. Its ureadful wickednefs has been fully proved. Every falthood, every deception with which it has been difguifed, has been compleatly done away; and it ftands before us in all its native horrors. No longer can it be pretended, that Africa is a barbarous, uncultivated land, inhabited by a race of favages inferior to the reft of the human fpecies. Mr. How, who was empioyed by gorernment to go up the country, depof 


\section{$(14)$}

that in land it is every where well cultirated, abound. ing with rice, millet, potatoes, cotton and judigs plantations; and that he inhabitanis are quick in learning languages, and romarkably indurrons, hofpitable and obliging. It appears that they pofeis noble and heroicminds, difdaning flavery, ari freguently feeking refuge from it in the arms of death. Nor fhall we be again told, of the fuperior hapinets they enjoy under the benerolent care of the planters; Mil. Coor having depofed, that "fetting flaves to work " in the morning, is attended with loud pents of " whipping;"--and General Tottenham, "thit thete " is no comparifon between reginental Logging, which " only cuts the fkin, and the fluntation, which cuts " cut the feth;"---Capt. Hill, " that the punih" ments are very flocking, much more fo then in " men of war;" Capt. Smith, " that at every ftroke " of the whip a piece of fleth is cut out,"--and hit. Rofs, "that he coniders a compatifon between Weft" Iindia faves, and the Eritifh pountry, as an infult "to common fenfe."

We are now called on to redichs evils, in comparifon with which, all that cxift in this nation finl beneath our notice; and the only facrifice we are reguired to make in order to ched it, is the abandoning of a luxury, wheh habit aione cais haverendered of imporance. If we refule, can we form the leant pretence to a moral chander? May it not be juftly infered, that thofe numerous difplays of humanity, of which this kingdom boafts, have not their foundation in any virtuous or valuable principle; but that to cuttum and oftentation they owe their origin? And if our execration of the flave trade be any more than merc declamation aganft crimes we are not in a fiuation to commit, we Rall, infend of being folicit- 


\section{$(15)$}

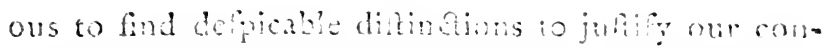

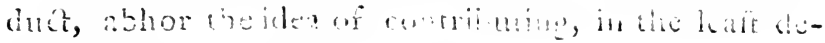
gree, to fuch feems of withy

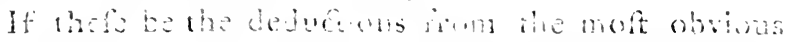

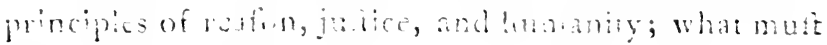

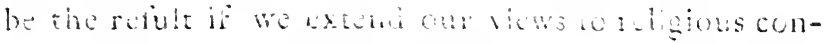
fickations? It whll hally be fild, that we aftume a

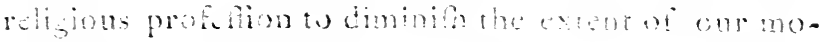
st datics, or to weakea the fored of our oblgation 10 oblervethem

Ye will therefore ans, if it be meant to bifute dio

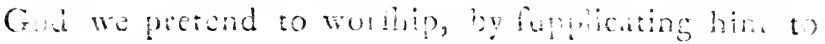
"have mercy upon all priforers and chives," arut to "defend and provige for the satherles, widows, and "chiliren, and all that are defol te and oppreted." Bur, if the national relgion be a mere matter of form, Yet furety we may exped that the ranous demominatons of difente:s, will thintst at hele it as reguifite to difent from the national crimes, as the nation. al religion; unlefs they mean to exhibit confoiences of fo peculiar a texture, as to take ofence at the ieligion of their country, while they can conform with out foruple, to its mot crinianl pratices, If indeed they are fatshed, after an immatal eximination, that the trafic alluded to is far and hoveft, and that the produce ought to be confide: ed as the refult of haw ful commerce, it will become them to cncoumge it; it vill become them to reprobate this work as an atteopt to flander honeft men, and to injure their propesiy, by holding it out to the public, as the produce of tobbery and murder. But, if the argunents be valid, will they prefume to treat the fubjed with cont indiffurence, and contiune a criminal pactice? May we not alfo hope that the Biethoths who apprar to feel

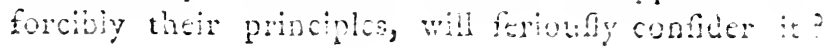




\section{$(16)$}

They are fo numerous, as to be able of themftres to deftroy that dreddoul tritic, which is the fole obtacle to their miniters freading the gofpel in the extentive continent of Africa; and, lowever othors may ancet to degracie the Negroes, they are bound to confider thounds of them as their boenten in Chrift.

But there is one clats of difturers who juthly ftand high in the public ettimation, for their fteady, manly and uniform oppofrtion to our colonial navery. And can it be fuppofed that, after haring awakened the public attention, they can refufe to contribute what is in their own power to remedy the evil? The plan propofed, is a plain and obvious dedution from their uniform principle, of having no concers in what they difapprove. Thus, confulering war as unlawful, they confider goods obtained though that medium as criminally obrained; and will not fuffer any of their members to purchaic prize-goods: and furely they muft confider the feizure of a man's gouds, as a crime fir infertor to the feizing his perfon.

Howerer obvious the duty, yet the mind hardened by habit, adnits with difficulty the conviction of guilt; and fanctioned by a common practice, we may commit the grofief violutions of dity without remorte. $r_{t}$ is therctore more pecuiariy incumbent on us in fach fituations, to examine our conduct with the utmoft fufpicion, and to fortify our minds with norai principles, or the fanctions of religion. In proportion as we are under their infiuence, we fuall exert ourfeives to remedy thefe evils, knowing that our txample, our adinonitions, our infuence, may produce remote effects, of which we can form no eftimate; and which, after having done our duty, muft be left to Him who gousrns all things after the coungel of his own will, F I I I . 


\section{P O S TSCRIPT,}

\section{Added to this American Edition.}

Contuning Extrans from an Exay. intitled, an insartial Enquiry into the State and Utility of the Province of Georgia; printed in Loindon in $174 \mathrm{I}$.

IV HEN Georgia was firf lettled, befides cther ufeful regulations, tho inhabitants were not allowed to have Nigro Slaves. No doubt their objections to them, were foundal fartly in civil policy, and partly from a fenfe of the injufice and crutely of that inhuman praffice, which dill not cperate, with eqnal force, upon the minds of all the inhouitants; fome of them being defirous of baving the benefit of their labour, without losking into confequences, in a remote degree, eitber as it respegted their cun perfonal fafety, or had an $i \cdots$ finence on the morals and happincls of their inmediate offspring, and their pofterity: with views fo contracted, fone foon greav dificontented with this fichitary reftraint, and fetitioned the Governor for liberty to bav'e faves. This produced ceunter fetilions, which leaves a farourable opinion of the wifdom ard virtue of fome of the firft fottlers of that flate, particularly of the Saltzunghers who fetiled at Eivenczer: thefe, to the number of $49 \mathrm{men}$, with their two minifiers, Jobn Riartili Rolziz's, and Ifrat Chripian Gronau, in a petition "befeech the bonourable trufiees (uf that fetticment) not to allsou that any Nonres mighes

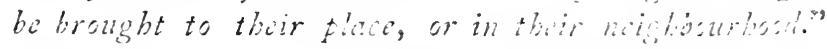

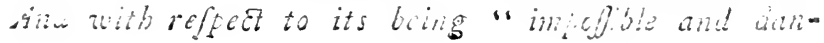




\section{POST S C PIPT.}

gerous for white feople to flant and manufacture rice" in that clinate, "as being a work only for Negroes, not for European people," they fay, "baring experience to the contrar, we laugh at fuch talkig, feeing that Several of us bave had a greater crop of rice late;car, than we wanted for our own confumition." And the inhabitants of Frederica, non the fame accafion, petitioncd againit baving Negroes introduced amongft them, "but dofifted from fending it, upon an afurance that their approbonfons of it were needless."

But the following petition of the Highlanders from Scotlind, who luad fettled at New-Inierness in Georgia is deferving of particular attention, as it contains fentiments congenial with thole advanced in the firgt of thele treatifes; and does credit to the difcernment, probity a.d bumanity of the ancefors of that fettement In tins petitioin they reminf rate to their then Governor Gglathorio, that they "were informed, "that ineir negghbours of Savazinab bad petitioned for "the liberty of baving funes;" in confequence of whib they fay, "Wo bope, and earnegll; cntreat, that be"fore fuch propofals are bearkentd unto, your Excei"lency will confader our fituation, and of what dan"gerous and bad confenuences fuch liberty would be of "to us." Thin after reciting fome of thefe they procecd:

"It is foocling to bunan nature, that any race "of monkind, and thir fofterity, frould be fon" tenced to perperua! favory; nor in juftice can we "think otherwife of it, than that they are thrown "amongft als to be our fourge, one duy or other, for "our fins : and as fruedom mult be as dear to thom " as to ats, what a fiene of horror mujt it bring " about! And tha longer it is unexecutod, the blac-

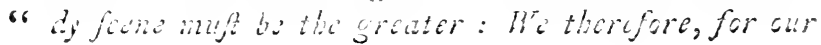





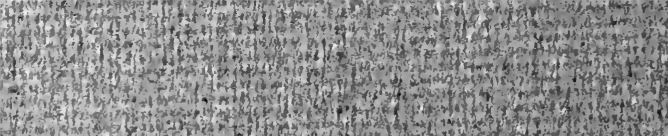
(3)

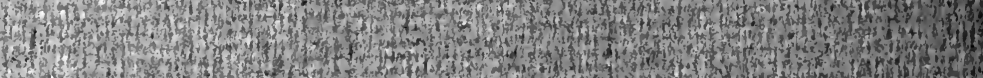
-

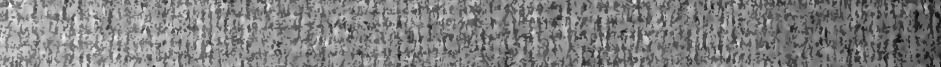
19.6.

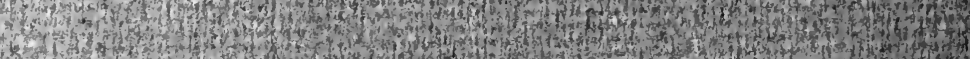

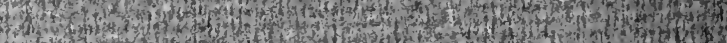

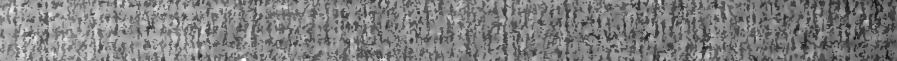

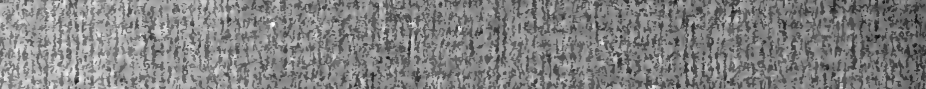

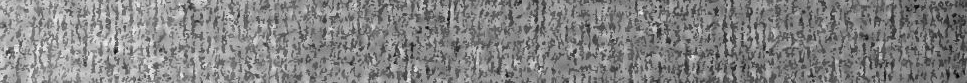

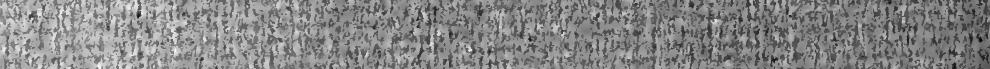

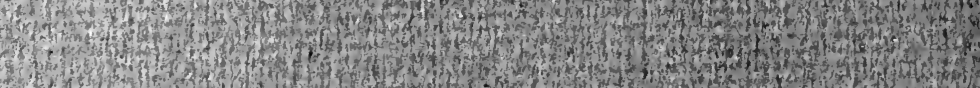

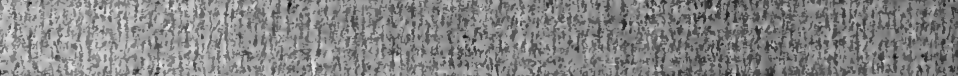
H.

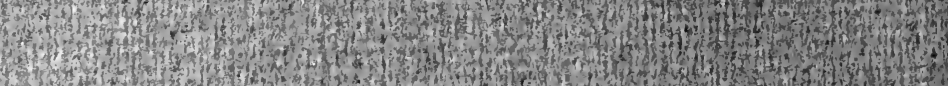

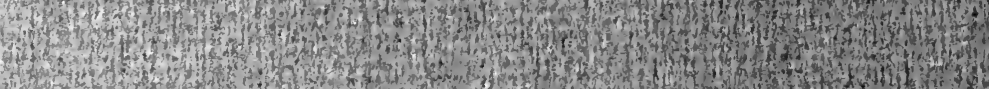

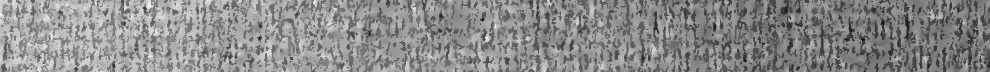

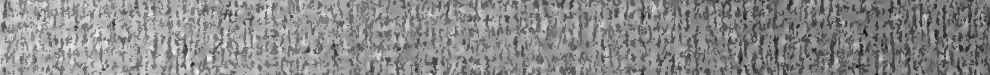
13.5. H.

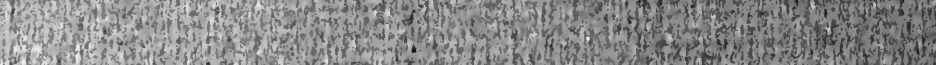

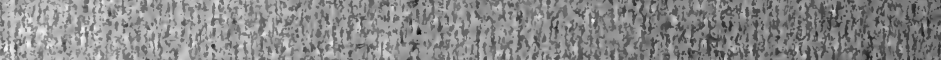

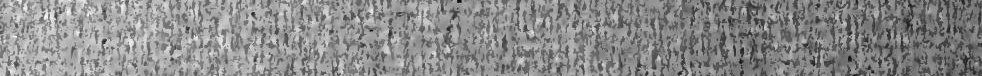

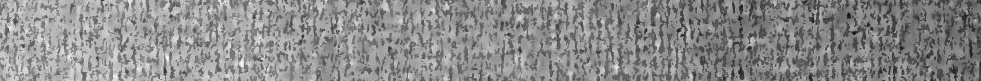

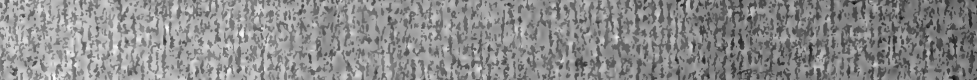

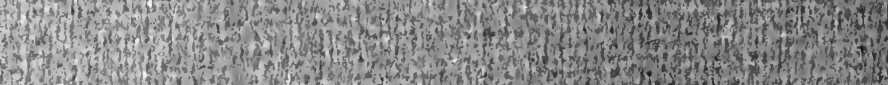

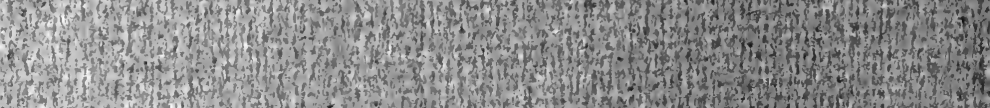

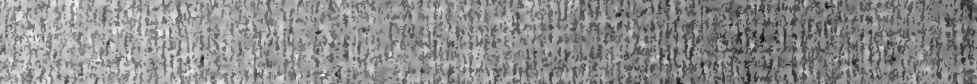

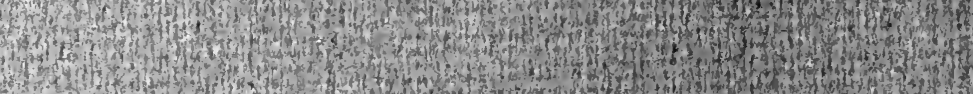

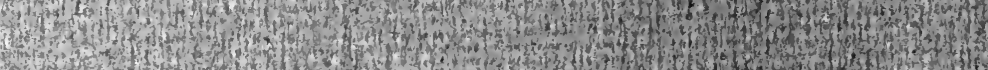

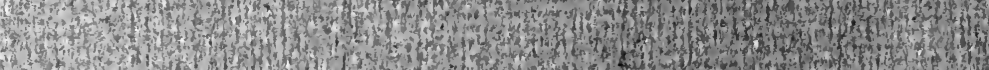
1.7.

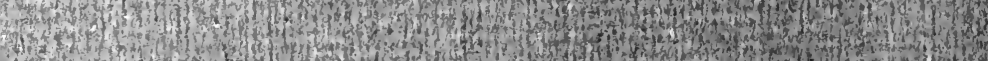
10
1

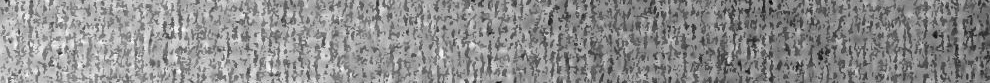
Hont

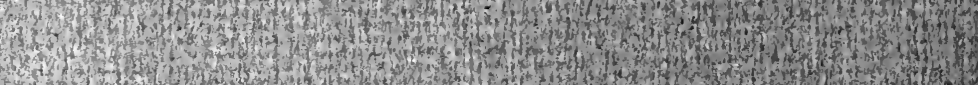

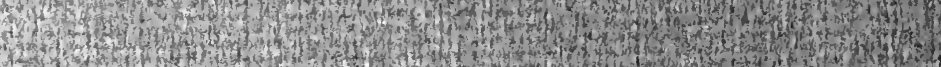
3. 